\title{
Efficacy of Ajaghrita (Goat ghee) in Vataja Netra Vikruti Lakshanas.(Vataja Opthalmic Disorders)
}

\author{
${ }^{1}$ Dr Mrs Madhuri P. Bhide ${ }^{2}$ Dr Mrs Savita S. Nilakhe \\ Principle Investigator, Co Investigator-
}

\begin{abstract}
Assessment criteria-
Subjective Parameters

1. Nistoda (Pricking Pain)

2. Sangharsha (Rubbing sensation)

3. Aadhmān (Bulging Sensation in eyes)

4. Sthabdhatā (Difficulty in ocular movement)

5. Netra Śş̧a (Atrophy and degenerative changes)

6. Netra Klama (Eye fatigue)

7. Śíira Aśrutā (Cold tears)

8. Kampana (Trembling in eyes)

9. Avil Netra (Turbid eyes)

10. Viśuśka Bhava (Dryness)

11. Alpa rāga (Slight rednees)
\end{abstract}

Abstract: Vataj Netra Vikruti" is the ophthalmic disorder occurred due to exasperation of Vayu in the ophthalmic tissue. The Vayu gets irritated due to overuse of eyes without any rest.. To prevent the diminishing phenomenon of tissues Ayurved has adviced to consume oleation. Cow Ghee and Goat Ghee are best Regenerative drugs either installed in eyes or if consumed orally.

Method-Aja Ghrit was prepared with strict hygienic precautions and step wise traditional method.

Diet- Patients were advised to stop spicy; hot; Salty food as it damages visual power as said by Acharya Sushruta,

Objective Parameters:

1) Tear film break up time 2) Vision test

Both tests were performed in ophthalmic O.P.D. at Bharati Vidyapeeth's Ayurved Hospital; Pune- 43 ;Maharashtra.

Dose:

Two drops in each eye, once in a day.

Duration: 15 days

Follow up: on 7th \& 14th day from the starting day of treatment.

Ethical Clearance:

Clinical Trials were started after obtaining ethical clearance

Conclusion-

Subjective Parameters-

Ajā Ghrita has proved significant in Nistoda, Sangharsha, Āadhmān, Netra Klama, Śiśira Aśrutā , Viśuśka Bhava, Alpa Rāga, Avil Netra. Non Significant results were found in Stabdhata and Netra Kampana.

Objective Parameters-

1) Tear Flim Break Up Test is used to measure the quality of the tear film. More the tear flim Cornea is moist.. As Viśuśka Bhava is well treated by instillation of Ajā Ghrita so Tear Flim Break Up Test has also proved significant.

2)Non Significant result was found for vision test. The drug was given for only 15 days, it should be administered for long duration of time to see its efficacy in vision test. 


\section{Introduction-}

The improper diet and wrong behavioural pattern has altered the ability of sense organs. All the Indriyas (Sense organs) are equally important but the Chakshu (eyes) is the foremost important of all .Damage to Chakshu (eye) leads to miserable life.

Worldwide 800 million patients suffer from ophthalmic disorders. Five to seven million people suffer from blindness. Five to seven million people require spectacles for reading and other close up activities. 145 million people have low vision due to uncorrected refractive errors. Women face greater risk of vision loss. 2/3 of blind people worldwide are women ${ }^{1}$.Early aging related macular degeneration, dry eye syndrome, presbiopia; ocular pain caused due to fatigue and ophthalmic nerve degeneration are the today's common problems .

"Vataj Netra Vikruti" is the ophthalmic disorder occurred due to exasperation of Vayu in the ophthalmic tissue. The Vayu gets irritated due to overuse of eyes without any rest. Continuous watching T.V; computer screen and other vibrant and glistening things increase Vayu and slowly damage the Occular tissues in degenerative way. To prevent the diminishing phenomenon of tissues Ayurved has adviced to consume oleation. Cow Ghee and Goat Ghee are best Regenerative drugs either consumed orally or if installed in eyes.

The current preventive and curative measures for these disorders are Vit A ; multivitamin treatment ;Zink and other nutritive supplements. These problems can be solved in the better way with adopting proper food and medicines regularly .

Amongst all the above beneficial factors, Goat Ghee is selected for this research project because it is "Cakshusya" as well as it has excellent vitality.

Attributes of Goat's ghee according to Sushrut samhita ${ }^{2}-$

\section{आजं घृतं दीपनीयं चक्षुष्यं बलवर्धनम् ।। (सु.स..४५/९८)}

\section{“Ajam Ghritam Dipaniyam Cakshshyam Balavardhanam”(su,Su 45/98)}

Vataj Netra Vikruti Lakshanas- ${ }^{3}$

\section{आल्पस्तु रागोड नुपदेहवांध्धा। \\ सतोदभोदोड निल्कजाक्षिरोगे ।। (च.चि. $\mathrm{QE} / \mathrm{Q} \mathrm{Q}$ )}

\section{"Alpastu rago anupdehavanshch}

Satodabhedo Anilaj Akshiroge" (charak samhita .cikitsasthanam 26/129)

Conventionally, the symptoms are mainly classified as Vataj, Pittaja and Kaphaja (i.e.developed due to dominant Vata; Pitta \& Kapha Dosha).Overuse of eyes and lack of proper nourishment of eye tissues leads to vitiation of Vayu. Vikruti."

The increased Vayu creates ocular pain; dryness and fatigue which are named as " Vataj Netra

Aschyotana' (installation) is a kind of local treatment for 'eye' which is implemented as eye drops . Goat ghee was administered as eye drops in the selected patients of Vataj Eye Disorder .Cow Ghee is most often used for this purpose as it is easily available.A lot of work has been performed on Cow Ghee . No research work has been done so far on Goat ghee as to assess its efficacy as Opthalmic drops. Hence this project was undertaken. The efficacy of goat's ghee in the Vataj eye disorders is explored in this research project with clinical approach.

\section{Aims and objectives-}

AIM - To study Efficacy of Ajaghrita(Goat's ghee) as ophthalmic drops in Vataj Netra Vikruti Lakshanas.

Materials:

\section{Materials And Method}

1. Goat Ghee

2. 50 patients having Vataj Netra Vikruti Lakshanas.

\section{Method:}

Preparation of Goat Ghee:

Goat milk was collected from the healthy goats residing at village in periphery of Distict Sangali ;Maharashtra. These Goats were fed Green Grass and were set free to roam for 4 to 5 hours per day. They were not given any medicine or extra food to increase milk output. Aja Ghrit was prepared with strict hygienic 
precaution and step wise traditional method. Butter was extracted from Goat milk curd after churning process and was again heated to prepare ghee. Since Goat milk contains less fat; from $\mathbf{3 4}$ liters of Aja milk only 330 ml of ghee was obtained.

\section{Preparation of CRF:}

Case Record Form was designed with the help of the compiled data of symptoms from Ayurvedic Texts and after discussion with Ophthalmologist. This includes subjective as well as objective parameters and Patient's Consent Form.

\section{Selection of Patients and drug administration:}

50 patients were selected for the study.

\section{ii) Inclusion criteria}

1. Clinically diagnosed patients having Vātaj Netra Vikṛtī Lakśnās were selected.

2. Sex - either sex

3. Age group - from 15 years to 50 years.

All people in this age group are in the educational phase or working. They are undergoing extensive use of computer, over reading, and exhaustive use of eyes. Hence to .minimise the Vatavriddhi this age group was selected.

\section{iii) Exclusion criteria}

a) Age below 15 years and above 50 years

b) Congenital ophthalmic anomalies.

c) Traumatic eye injuries.

d) Asādhya and Darun (incurable and deserving emergency treatment)

The children below 15years of age have dominance of Kapha and usually do not suffer from Vataj Disorders..So they were excluded. The people in the age group of more than 50 years have already dominance of Vāta, . Due to senility Aggravated Vata causes degenerative changes which are irreversible and hence are excluded from study.

Dose:

Two drops in each eye, once in a day.

Duration: 15 days

FOLLOW-UP: on $7^{\text {th }} \& 14^{\text {th }}$ day from the starting day of treatment.

\section{Assessment criteria-}

\section{1) Subjective Parameters ${ }^{4}$ \\ ÊxÉO iÉÉänüxÉÆ

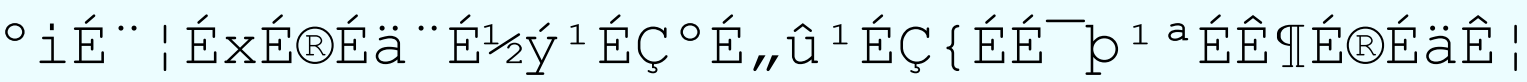 ÉiÉÉ \{ÉÉ : **

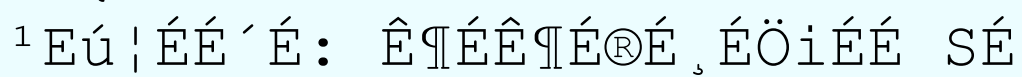

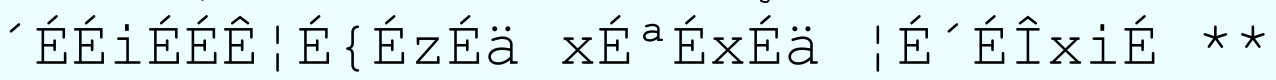 \\ "Nistodanam Stambhan romaharsha samgharsha parushya shirobhitapah" Vishushkabhavah Shishir ashruta ch Vatabhipanne Nayane Bhavanti”}

1. Nistoda (Pricking Pain)

2. Sangharsha (Rubbing sensation)

3. Āadhmān (Bulging Sensation)

4. Sthabdhatā (Difficulty in ocular movement) 
5. Netra Śoşa (Atrophy and degenerative changes)

6. Netra Klama (Eye fatigue)

7. Śiśira Aśrutā (Cold tears)

8. Kampana (Trembling in eyes)

9. Avil Netra (Turbid eyes)

10. Viśuśka Bhava (Dryness)

11. Alpa rāga (Slight rednees)

\section{2) Objective Parameters:}

1) Tear film break up time ( T.F.B.U.T)

2) Vision test

Both tests were performed in ophthalmic O.P.D. at Bharati Vidyapeeth's Ayurved Hospital Pune 43 ;Maharashtra.

\section{Tear Film Break Up Time:}

Tear film break up time has been defined as the interval between the complete blink and the appearance of the first randomly distributed dry spot. The T.F.B.U.T. is measured by instilling fluorescein solution into the conjunctival sac and scanning the cornea with cobalt blue filter illumination at the slit lamp microscope for the first sign of dry (fluorescein free) areas. The normal tear film B.U.T. is 10-35 secs. And readings of less than 10 seconds suggest mucin deficiency. As uniform normal wetting of the corneal surface depends on even spreading of the adsorbed mucin layer, then the rapidity of appearance of dry spots on the cornea between blinks becomes an index of the adequacy of the mucin layer. T.F.B.U.T. was used to measure the quality of the tear film. This test was done as follows, between the complete blink This test was done as follows,

A moistened fluorescein strip was applied to the inferior temporal bulbar conjunctiva. Patients were instructed to blink several times to facilitate an even distribution of fluorescein. The patient was then positioned for slit lamp examination and asked to stare directly ahead without blinking or holding the lids after one complete blink. The tear film was then scanned through a cobalt blue filtered light by magnification and broad vertical beam. A stopwatch was used to measure the interval between the last complete blink and the first appearance of a randomly distributed dry spot, the T.F.B.U.T. Three consecutive readings were taken in each eye and the mean value of these readings were considered above 10 seconds as normal and less than 10 seconds as cases of dry eyes. Observations were noted according to signs and symptoms with gradations as follows:

\section{T.F.B.U.T. -}

O - Normal - In Seconds. > 10,

+- Mild $--+=8$ to 10 .

++- Moderate $=5$ to $7,+++-$ Severe $--<5$

\section{Drug administration:}

1.Ethical Clearance:

Clinical Trials were started after obtaining ethical clearance from Institutional Ethical Committee.

2.Patients were supplied sterile plastic bottles with $5 \mathrm{ml}$ Aja Ghrita in each bottle. The patients were taught the" Ashchotan procedure" in strict hygienic method when Ghrita was instilled in the morning patient had discomfort. So it was decided to instill eye drops in the evening.

Initially patients were administered 8 drops as per textual reference-- .

\section{बिन्दवोऽष्टौ रेखनेषु स्नेहने दश बिन्दव:। \\ रोपणे द्वादश प्रोक्तास्ते शीते कोष्णरुपऩण् $\|^{5}$}

\section{"Bindavo ashtaou lekhaneshu snehane dash bindavah" Ropane dwadasha proktaste sheete koshnarupanan"}

It was observed that only 1 or 2 drops were absorbed in eyes. Rest of the medicine was flown away. Hence patients were advised to install 2 drops in each eye.

The patients were examined subjectively on each follow - up day with help of case paper. The severity of symptoms was noted each time.Gradation of symptoms was done accordingly before and after treatment.Patients were advised to avoid diet which is harmful to eyes such as hot strong and pungent food material. 
Drop out- The patients who complained discomfort; itching or redness due to Ashchotan were dropped out. There were total 7 patients who were dropped out. Ayurvedic texts explain contraindication of oleation when the patient is suffering from indigestion.These patients were having symptoms of indigestion like constipation; loss of appetite and flatulence

\section{Subjective Parameters-}

\section{Observations}

After follow up with time interval of seven days and scrutiny of all case papers statistical analysis was done. Following observations are recorded

1) Significant Results- Ajā Ghṛita has proved significant in Nistoda(Pricking Pain) (, Sangharsha(Rubbing sensation), Āadhmān ((Bulging Sensation), Netra Klama(Eye fatigue), Śiśira Aśrutā (Cold tears), Viśuśka Bhava(Dryness), Alpa Rāga, (Slight rednees) Avil Netra(Turbid eyes).

2) Non Significant results were found in Stabdhata and Netra Kampana. In present study Ajā Ghrita was given in Ashchyotan form. If it is given in the form of Tarpan significant results could be seen in Stabdhata and Netra Kampana.

\section{Objective Parameters-}

1) Tear Flim Break Up Test ${ }^{7,8}$ is used to measure the quality of the tear film. More the tear flim Cornea is moist.. As Viśuśka Bhava is well treated by instillation of Ajā Ghrita so Tear Flim Break Up Test has also proved significant.

2)Non Significant result was found for vision test. The drug was given for only 15 days, it should be administered for long duration of time to see its efficacy in vision test.

3)The Vātaj Netra Vikrutī Lakśanas were observed higher in the group of 15 to 30 years \& minimum in the patient above the 45 to 60 years.

3) The incidence of Vāttaj Netra Vikruti Lakśanas was observed higher in patients doing minute work, reading books or watching television.

4) Vāttaj Netra Vikruti Lakśanas were observed higher in patients taking Achakshusya Ahar. These patient were consuming Salty and spicy Diet more than three days per week.

\section{Conclusion}

1. Ajā Ghrita is significant in Vāttaj Netra Vikruti Lakśanas.

2] Ajā Ghrita has proved highly significant in the symptoms- Viśuśka Bhava', 'Nistoda' and ' Netra Klama' .

3] Ajā Ghrita has proved highly significant in dryness assessed by TFBUT.

4) Ajā Ghrita is non- significant in the improvement of vision assessed by vision test.

\section{References-}

[1]. W.H.O. Visual impairment and blindness fact sheet. N 282 http//w.w.w...who. int/ mediacentre/ factsheet).

[2]. Sushrut Samhita of Sushrut with Nibandh Sangraha Commentry. (Su Su 45/98)

[3]. Charak Samhita- withAyurved Dipika of- Chakrapani commentary.(c .ci-26-129)

[4]. Sushrut Samhita- Nibandha Samgraha commentary (Uttartantra-6/6)

[5]. Yoga Ratnakar with Vidyotini Teeka by vd.Laxmipati Shastri Choukhamba Sanskrit Bhavan Varanasi 1983

[6]. Sushrut Samhita of Sushrut with Nibandh Sangraha Commentry. - Uttartantra-6/6

[7]. N.Seals's Text Book of Opthalmology by S K Seal;current books international. $5^{\text {th }}$ edition Kolkata.

[8]. Essentials ofOpthalmology by Sumer k Basak.Current books international; $2^{\text {nd edition }}$ Kolkata 